\title{
Author Correction: Host-associated niche metabolism controls enteric infection through fine- tuning the regulation of type 3 secretion
}

\author{
James P.R. Connolly (1) ${ }^{1}$, Sabrina L. Slater ${ }^{2}$, Nicky O'Boyle ${ }^{1}$, Robert J. Goldstone ${ }^{3}$, Valerie F. Crepin², \\ David Ruano-Gallego (1) ${ }^{2}$, Pawel Herzyk ${ }^{4}$, David G.E. Smith (10) ${ }^{3}$, Gillian R. Douce ${ }^{1}$, Gad Frankel (i) ${ }^{2} \&$ \\ Andrew J. Roe ${ }^{1}$
}

Correction to: Nature Communications. doi: https://doi.org/10.1038/s41467-018-06701-4; published online 10 Oct 2018

The original version of this Article contained an error in the spelling of the author David Ruano-Gallego, which was incorrectly given as David R. Gallego. This has now been corrected in both the PDF and HTML versions of the Article.

Published online: 29 November 2018

\begin{abstract}
(c) (i) Open Access This article is licensed under a Creative Commons Attribution 4.0 International License, which permits use, sharing, adaptation, distribution and (c) reproduction in any medium or format, as long as you give appropriate credit to the original author(s) and the source, provide a link to the Creative Commons license, and indicate if changes were made. The images or other third party material in this article are included in the article's Creative Commons license, unless indicated otherwise in a credit line to the material. If material is not included in the article's Creative Commons license and your intended use is not permitted by statutory regulation or exceeds the permitted use, you will need to obtain permission directly from the copyright holder. To view a copy of this license, visit http://creativecommons.org/licenses/by/4.0/.
\end{abstract}

(c) The Author(s) 2018

\footnotetext{
${ }^{1}$ Institute of Infection, Immunity and Inflammation, University of Glasgow, Glasgow G12 8TA, UK. ${ }^{2}$ MRC Centre for Molecular Bacteriology and Infection, Department of Life Sciences, Imperial College, London SW7 2AZ, UK. ${ }^{3}$ School of Life Science, Heriot-Watt University, Edinburgh EH14 4AS, UK. ${ }^{4}$ Glasgow Polyomics, Wolfson Wohl Cancer Research Centre, University of Glasgow, Garscube Estate, Glasgow G61 1QH, UK. Correspondence and requests for materials should be addressed to J.P.R.C. (email: James.Connolly@glasgow.ac.uk) or to A.J.R. (email: Andrew.Roe@glasgow.ac.uk)
} 